\title{
PENERAPAN MODEL PEMBELAJARAN KOOPERATIF TIPE JIGSAW PADA MATERI BANGUN RUANG SISI DATAR
}

\author{
LIA S \\ SMP Negeri 2 Muaro Jambi \\ Email : liahidayat0082@gmail.com
}

\begin{abstract}
ABSTRAK
Kurang aktifnya siswa dalam pembelajaran matematika menyebabkan hasil belajar yang tidak memuaskan atau tidak mencapai $\mathrm{kkm}$. Hal ini dapat disebabkan salah satunya dengan metode guru yang kurang memotivasi siswa dalam belajar.Melihat kenyataan tersebut di atas, maka penulis berusaha membuat inovatif dalam pembelajaran matematika untuk mengaktifkan siswa dalam pembelajaran matematika. Hal ini diharapkan agar siswa termotivasi dan terangsang untuk lebih aktif dalam belajar. Jika siswa telah aktif dalam belajar, maka materi yang dipelajari dapat diterima dengan mudah dan rasa senang. Salah satu metode yang diterapkan adalah model pembelajaran kooperatif tipe jigsaw. Subjek pada penelitian ini adalah siswa Kelas VIIIB dengan jumlah siswa 32 orang dan waktu penelitian ini berlangsung selama 2,5 pekan dengan melalui 2 siklus. Dengan penerapan pembelajaran kooperatif tipe jigsaw ini, ternyata hasil belajar siswa meningkat dari nilai siklus I ke siklus II untuk bangun ruang sisi datar dengan materi menentukan luas permukaan kubus, balok, prisma dan limas. Hal ini terlihat dari penilaian formatif yang telah diberikan. Untuk itu penulis berharap, hasil penelitian ini dapat memberikan sumbangsih terhadap peningkatan mutu pendidikan umumnya dan menjadi khasanah inovatif pembelajaran matematika, khususnya di kelas.
\end{abstract}

Kata Kunci : Model Pembelajaran Kooperatif Tipe Jigsaw , Bangun Ruang Sisi Datar.

\section{PENDAHULUAN}

Pendidikan di Indonesia diselenggarakan bertujuan untuk mencerdaskan kehidupan bangsa. Upaya pemerintah diwujudkan dengan memperbaiki kurikulum. Penerapan kurikulum tingkat satuan pendidikan di SMP sangat dipengaruhi oleh guru dalam menyusun silabus, sistem penilaian dan penerapan penggunaan model pembelajaran. Penguasaan dan pemahaman suatu ilmu yang akan diajarkan seorang guru kepada siswa harus mempunyai model pembelajaran yang menarik, mudah untuk dipahami dan dimengerti siswa. Selain hal tersebut, seorang guru dituntut untuk mengenal berbagai jenis model pembelajaran, agar terampil dan dapat memilih model pembelajaran yang tepat dalam pelaksanaan kegiatan belajar mengajar.

Penyusunan model pembelajaran yang dipilih harus sesuai dengan materi pelajaran yang akan disampaikan, karena pemilihan model pembelajaran yang tepat akan membantu tercapainya tujuan pengajaran. Khusus untuk mata pelajaran matematika pokok bahasan Bangun Ruang Sisi Datar pada kelas VIII semester II untuk kurikulum 2013, dari tahun ketahun tidak menunjukan peningkatan hasil belajar yang berarti. Siswa tampaknya sangat kesulitan memahami materi ini, padahal dari tingkat SD materi ini telah disampaikan sebelumnya. Bangun ruang sisi datar pada dasarnya bukanlah materi pelajaran yang teramat sulit, karena sering dijumpai dalam kehidupan sehari-hari, seperti kubus, balok, proisma dan limas.

Dari hasil ulangan harian untuk pokok bahasan Bangun ruang sisi datar di SMP N 2 Muaro Jambi kelas VIII pada tahun-tahun sebelumnya, khusus untuk kompetensi dasar menentukan luas permukaan dan volume bangun ruang sisi datar (kubus, balok, limas dan prisma) untuk indikator yang ambil adalah menentukan luas permukaan kubus dan balok dengan menggunakan alat peraga yang nyata setelah dianalisis ternyata peserta didik banyak mengalami kesulitan untuk mengerjakan soal menentukan luas permukaaan kubus dan balok sehingga hasil ulangan pun banyak yang tidak mencapai nilai tuntas. 
Vol 1. No. 3, Juli 2021 P-ISSN : 2774-8030, e-ISSN : 2774-8030

Tabel 1. Rata-rata nilai ujian siswa

\begin{tabular}{|c|c|c|}
\hline Tahun Pelajaran & Nilai Rata-rata & KKM \\
\hline $2015 / 2016$ & 55 & 65 \\
\hline $2016 / 2017$ & 60 & 65 \\
\hline $2017 / 2018$ & 63 & 70 \\
\hline $2018 / 2019$ & 67 & 75 \\
\hline
\end{tabular}

Untuk itulah peneliti berusaha mengadakan penelitian bagaimana memecahkan masalah ini. Salah satunya dengan mengadakan perubahan model pembelajaran yang selama ini dipakai untuk proses pembelajaran siswa. Adanya pemilihan model pembelajaran dan media pembelajaran yang tepat dalam proses pembelajaran diharapkan dapat membantu meningkatkan penguasaan materi tentang bangun ruang sisi datar ini dan sekaligus siswa dapat lebih aktif dalam kegiatan belajar mengajar. Menurut Lie (2004) Pembelajaran kooperatif merupakan model pembelajaran alternatif untuk mencapai tujuan pembelajaran matematika yang antara lain berupaya untuk meningkatkan kemampuan siswa dalam bekerja sama, berpikir kritis, dan meningkatkan prestasi akademik. Model pembelajaran kooperatif merupakan teknis-teknis kelas praktis yang dapat digunakan guru setiap hari untuk membantu siswa belajar mulai darai keterampilan dasar sampai pemecahan masalah yang komples (Nur,2011:1).

Tabel 2. Sintaks Bentuk Pembelajaran Kooperatif

\begin{tabular}{|c|c|}
\hline Fase & Tingkah laku guru \\
\hline $\begin{array}{l}\text { Fase } 1 \\
\text { Menyampaikan tujuan } \\
\text { dan memotivasi siswa }\end{array}$ & $\begin{array}{l}\text { Guru menyampaikan semua tujuan } \\
\text { pelajaran yang ingin dicapai pada } \\
\text { pelajaran tersebut dan memotivasi siswa. }\end{array}$ \\
\hline $\begin{array}{l}\text { Fase } 2 \\
\text { Menyajikan informasi }\end{array}$ & $\begin{array}{l}\text { Guru menyajikan informasi kepada siswa } \\
\text { dengan jalan demonstrasi atau lewat } \\
\text { bacaan }\end{array}$ \\
\hline $\begin{array}{l}\text { Fase } 3 \\
\text { Mengorganisasikan siswa } \\
\text { ke dalam kelompok } \\
\text { belajar }\end{array}$ & $\begin{array}{l}\text { Guru menjelaskan kepada siswa } \\
\text { bagaimana caranya membentuk } \\
\text { kelompok belajar dan membantu setiap } \\
\text { kelompok agar melakukan transisi secara } \\
\text { efesien. }\end{array}$ \\
\hline $\begin{array}{l}\text { Fase } 4 \\
\text { Membimbing kelompok } \\
\text { bekerja dan belajar }\end{array}$ & $\begin{array}{l}\text { Guru membimbing kelompok-kelompok } \\
\text { belajar pada saat mereka mengerjakan } \\
\text { tugas }\end{array}$ \\
\hline $\begin{array}{l}\text { Fase } 5 \\
\text { Evaluasi }\end{array}$ & $\begin{array}{l}\text { Guru mengevaluasi hasil belajar tentang } \\
\text { materi yang sudah dipelajari atau masing- } \\
\text { masing kelompok mempresentasikan } \\
\text { hasil kerjanya }\end{array}$ \\
\hline $\begin{array}{l}\text { Fase } 6 \\
\text { Memberikan } \\
\text { penghargaan }\end{array}$ & $\begin{array}{l}\text { Guru mencari cara-cara untuk } \\
\text { menghargai upaya atau hasil belajar } \\
\text { individu atau kelompok }\end{array}$ \\
\hline
\end{tabular}

Pada pembelajaran kooperatif siswa akan bekerjasama di dalam kelompok untuk mempelajari suatu materi dan akan mendapatkan pengalaman individu maupun kelompok. Setiap kelompok biasanya terdiri dari siswa yang memiliki kemampuan yang berbeda. Dalam menyelesaikan tugas kelompok, setiap siswa anggota kelompok harus saling bekerja sama dan 
saling membantu untuk memahami materi pelajaran, belajar kelompok memungkinkan siswa terlibat aktif dalam belajar karena siswa mempunyai tanggung jawab belajar yang lebih besar dan memungkinkan berkembangnya daya kreatif dan sifat kepemimpinan pada siswa. Guru berperan sebagai organisator kegiatan belajar-mengajar, sumber informasi bagi siswa, pendorong bagi siswa untuk belajar, serta penyedia materi dan kesempatan belajar bagi siswa. Salah satu model pembelajaran kooperatif yang telah di kembangkan adalah jigsaw, Model pembelajaran tipe jigsaw merupakan salah satu temuan baru untuk memperbaiki model pembelajaran dalam dunia pendidikan.

Model pembelajaran tipe jigsaw pertama kali dikembangkan dan diujicobakan oleh Elliot Aronson dan teman-teman di Universitas Texas, dan kemudian diadaptasi oleh Slavin dan teman-teman di Universitas John Hopkins (Arends,1997). Penelitian sebelumnya menunjukkan bahwa model pembelajaran tipe jigsaw ini cocok diterapkan di kelas. Hasil penelitian Titis Prabaningrum (2016) menunjukkan bahwa penerapan model pembelajaran kooperatif tipe jigsaw dapat meningkatkan motivasi belajar dan hasil belajar siswa kelas XI SMA Negeri 1 Sidoharjo. Penelitian oleh Fitriani (2007) dengan pembelajaran kooperatiftipe jigsaw juga menunjukkan peningkatan hasil belajar siswa kelas VIII di SMP Negeri 4 Palu. Slavin (dalam Raharja, 2002: 4) juga melaporkan 45 judul penelitian selama 14 tahun menyelidiki pengaruh pembelajaran kooperatif terhadap hasil belajar siswa di sekolah.

Berbagai hasil temuan penelitian di atas, maka peneliti tertarik melakukan penelitian dengan menerapkan model pembelajaran kooperatif tipe jigsaw dari beberapa permasalahan dalam proses pembelajaran siswa di kelas VIII SMP Negeri 2 Muaro Jambi khususnya untuk materi bangun ruang sisi datar.

\section{METODE PENELITIAN}

Penelitian ini dilaksanakan selama lebih kurang 2,5 pekan dari tanggal 24 Februari 2020 sampai 14 Maret 2020 di SMP Negeri 2 Muaro Jambi, Jenis penelitian ini adalah penelitian tindakan kelas (PTK) atau Classroom Action Research. Penelitian tindakan kelas ini adalah usaha guru untuk mencari solusi tentang permasalahan yang terjadi didalam proses belajar mengajar di dalam kelas. Menurut Suharsimi Arikunto (2013:8) bahwa penelitian tindakan kelas ini dilaksanakan langsung oleh guru sebagai penanggung jawab dengan tujuan utama untuk meningkatkan hasil pembelajaran dikelas. .Menurut model ini, PTK terdiri dari atas 4 komponen atau 4 tahap yaitu (1) perencanaan, (2) tindakan, (3) pengamatan dan (4) refleksi. Dan kegiatan ini terdiri dari dua siklus pada materi bangun ruang sisi datar dalam menentukan luas permukaan kubus,balok, prisma dan limas. 


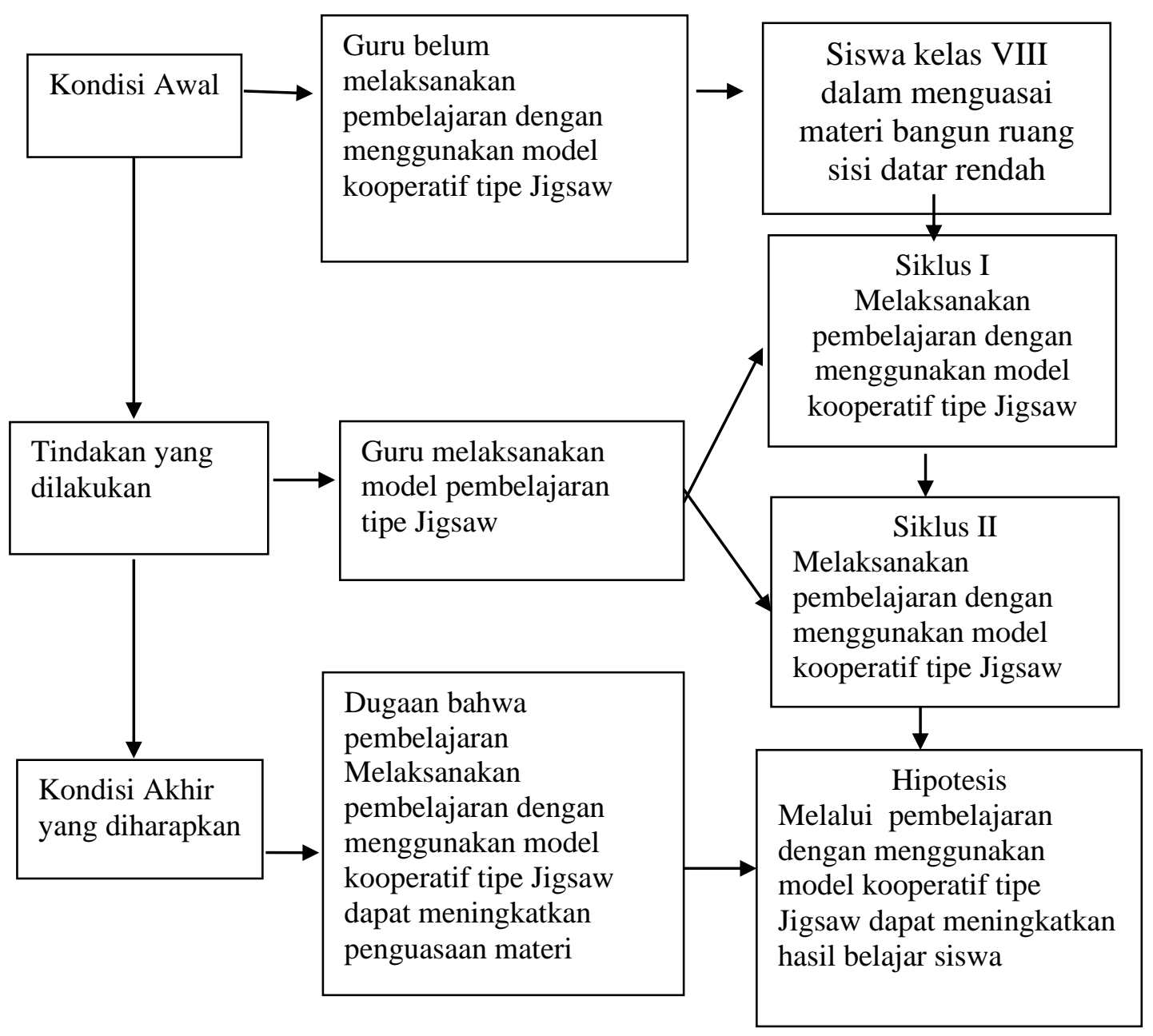

Gambar 1. Grafis pemikiran yang dilakukan oleh peneliti

\section{HASIL DAN PEMBAHASAN}

\section{A. SIKLUS I}

Rencana tindakan yang diberikan pada siklus pertama sesuai dengan yang telah diprogramkan antara lain : Menyusun Rencana Pembelajaran (RPP), menyusun lembar kerja siswa (LKS) perkelompok, mempersiapkan media pembelajaran yang dipakai pada saat proses pembelajaran, dan mempersiapkan lembar evaluasi untuk masing-masing siswa. Misalnya pada saat pengelompokan untuk masing-masing siswa duduk sesuai dengan kelompoknya masing-masing, situasi kelas menjadi ribut apalagi saat mengatur tempat duduk dan meja perkelompok. Pembagian anggota kelompok disesuai dengan kemampuan masingmasing siswa, sehingga dalam tiap-tiap kelompok mempunyai kemampuan yang merata dalam hal kemampuan akademiknya. Pembelajaran menggunakan model pembelajaran kooperatif tipe jigasaw, siswa dari tim yang berbeda dan mempunyai materi serta soal yang sama bergabung kembali untuk membentuk kelompok baru yang disebut dengan tim ahli. Pada saat berlangsungnya proses diskusi di masing-masing kelompok tim ahli, kelihatan siswa sangat antusias untuk mengerjakan soal-soal tersebut.

Pada awal siklus I evaluasi akhir KBM tidak dapat terlaksana karena waktu yang banyak tersita untuk mengatur siswa pada saat kegiatan kelompok tadi. Pada siklus pertama ini jalannya, diskusi antara siswa dalam masing-masing kelompok masih belum terlaksana sebagaiman mestinya, karena tidak semua siswa memiliki kemampuan verbal yang bagus untuk bisa menjelaskan cara penyelesaian soal-soal tersebut. Setelah dilakukan serangkaian kegiatan belajar mengajar dengan menggunakan metode Jigsaw di kelas VIIIB dalam kegiatan 
siklus 1, diperoleh gambaran mengenai hasil belajar pada mata pelajaran matematika khususnya dalam menentukan luas dan permukaan bangun datar melalui hasil tes formatif atau soal-soal yang mengukur kemampuan siswadalam menguasai materi yang diberikan. Berikut ini gambaran hasil balajar siswa :

Tabel 3. Data Hasil Belajar Siswa Siklus I

\begin{tabular}{|c|c|c|c|}
\hline Kriteria & Nilai & Siswa & Persentase \\
\hline Tuntas & $75-100$ & 13 & 41 \\
\hline Tidak Tuntas & $0-74$ & 19 & 59 \\
\hline Jumlah & & 32 & $100 \%$ \\
\hline
\end{tabular}

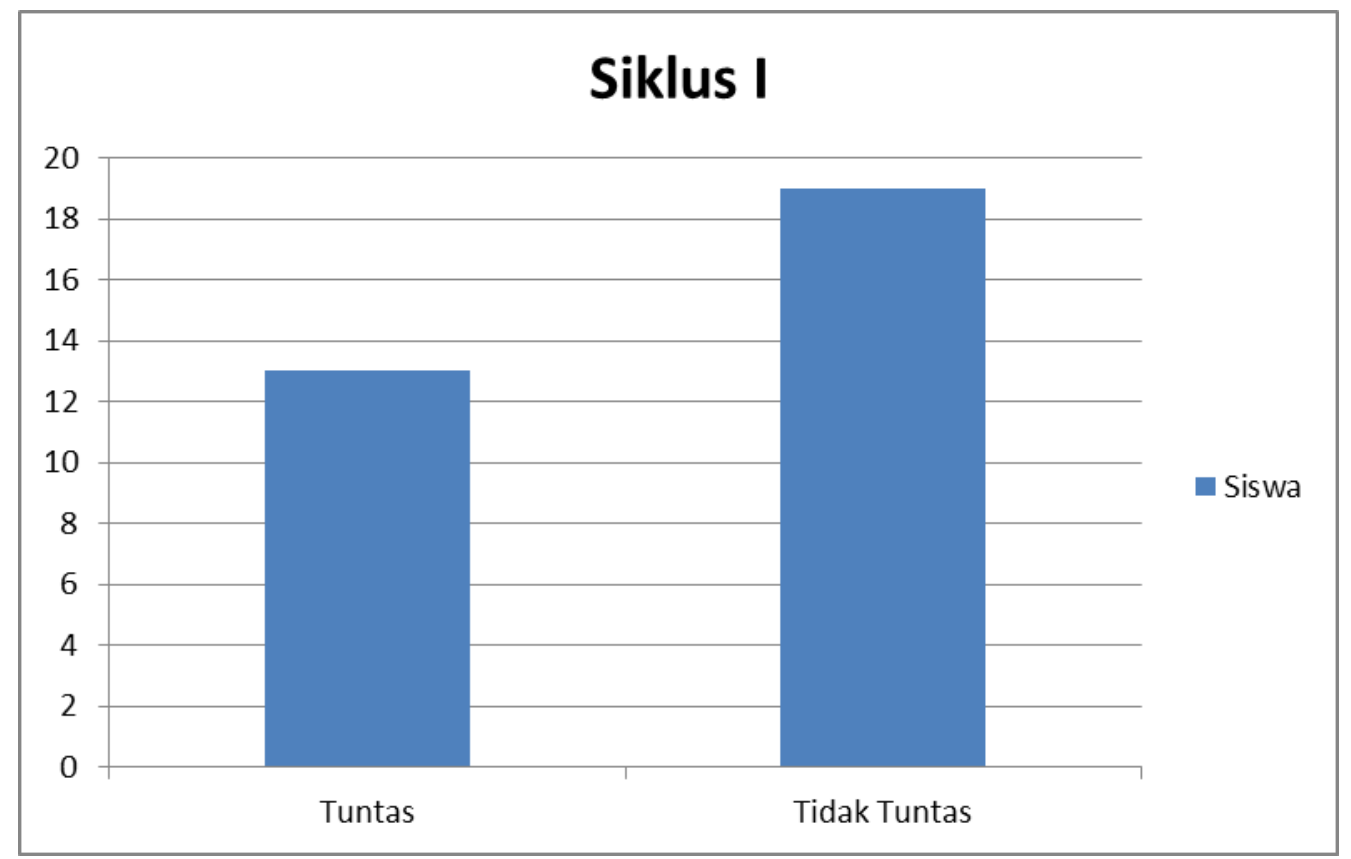

Gambar 2. Grafik hasil belajar siswa pada Siklus I

\section{B. SIKLUS II}

Pada tahap ini peneliti menyusun tindakan yang akan dilakukan selama penelitian tindakan kelas, tindakan ini merupakan tindakan yang perlu diperbaiki pada siklus I, seperti memperbaiki RPP. Pelaksanaan pembelajaran mengacu pada RPP yang telah disusun yaitu materi menghitung luas permukaan dan volume bangun ruang sisi datar untuk kelas VIIIB dalam kategori baik dengan rata-rata 75 dengan nilai KKM 75. nilai diatas diperoleh setelah siswa mengikuti tes yang diberikan guru. Berdasarkan hasil observasi pembelajaran pada siklus II sudah lebih baik. Hasil belajar siswa dalam materi menghitung luas dan volume bangun ruang meningkat dari sebelumnya. Beberapa siswa bahkan mendapatkan nilai sempurna dalam mengerjakan soal yang diberikan guru. Siswa juga terlihat aktif dalam kelompok, mereka memiliki rasa percaya diri yang lebih baik dalam memberikan penjelasan kepada temannya yang mengalami kesulitan dalam mengerjakan soal. Refleksi Hasil dari siklus II menunjukkan bahwa pelaksanaan pembelajaran berjalan lebih baik. Keaktifan siswa didalam kelas meningkat secara signifikan dan hasil belajar siswa juga lebih baik dari siklus I.

Tabel 4. Data Hasil Belajar Siswa Siklus II

\begin{tabular}{|c|c|c|c|}
\hline Kriteria & Nilai & Siswa & Persentase \\
\hline Tuntas & $75-100$ & 26 & 81 \\
\hline Tidak Tuntas & $0-74$ & 8 & 19 \\
\hline Jumlah & & 32 & $100 \%$ \\
\hline
\end{tabular}


Vol 1. No. 3, Juli 2021 P-ISSN : 2774-8030, e-ISSN : 2774-8030

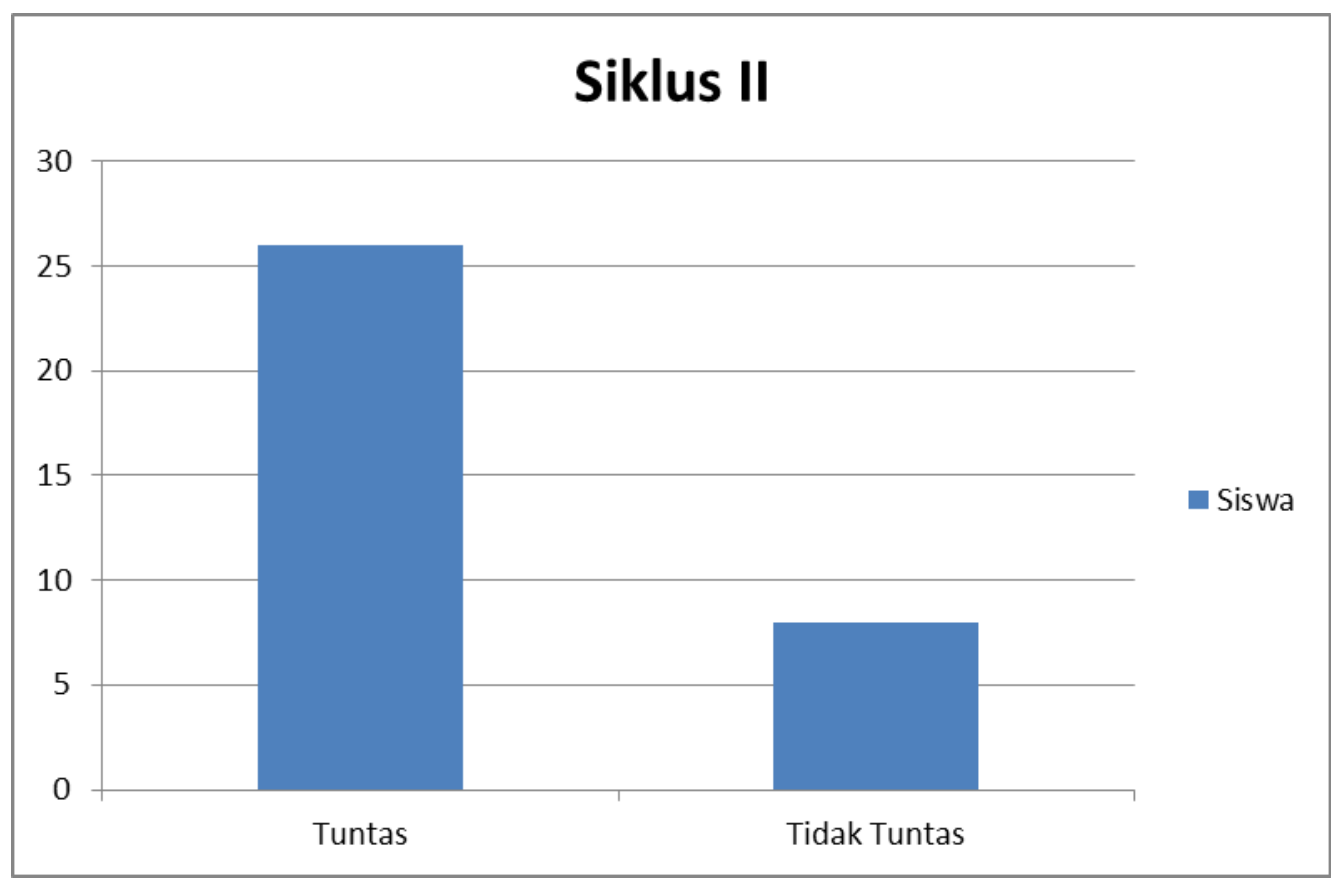

Gambar 3. Grafik hasil belajar siswa pada Siklus I

Dari tabel dan grafik dapat dilihat adanya peningkatan yang signifikan dari siklus I ,siswa yang tuntas 26 orang atau mencapai $81 \%$ ini menggambarkan bahwa proses pembelajaran pada siklus II lebih baik walaupun masih ada siswa yang belum tuntas 8 orang atau $19 \%$ dari jumlah keseluruhan.

Tabel 5. Perbandingan Hasil Belajar Siswa Pada Siklus I dan Siklus II

\begin{tabular}{|c|c|c|c|c|}
\hline \multirow{2}{*}{ Kriteria } & \multicolumn{2}{|c|}{ Siklus 1 } & \multicolumn{2}{c|}{ Siklus 2 } \\
\cline { 2 - 5 } & Siswa & Persentase & Siswa & Persentase \\
\hline Tuntas ( 75-100) & 13 & 41 & 26 & 81 \\
\hline Tidak Tuntas (0-74) & 19 & 59 & 8 & 19 \\
\hline Jumlah & 32 & $100 \%$ & 32 & $100 \&$ \\
\hline
\end{tabular}

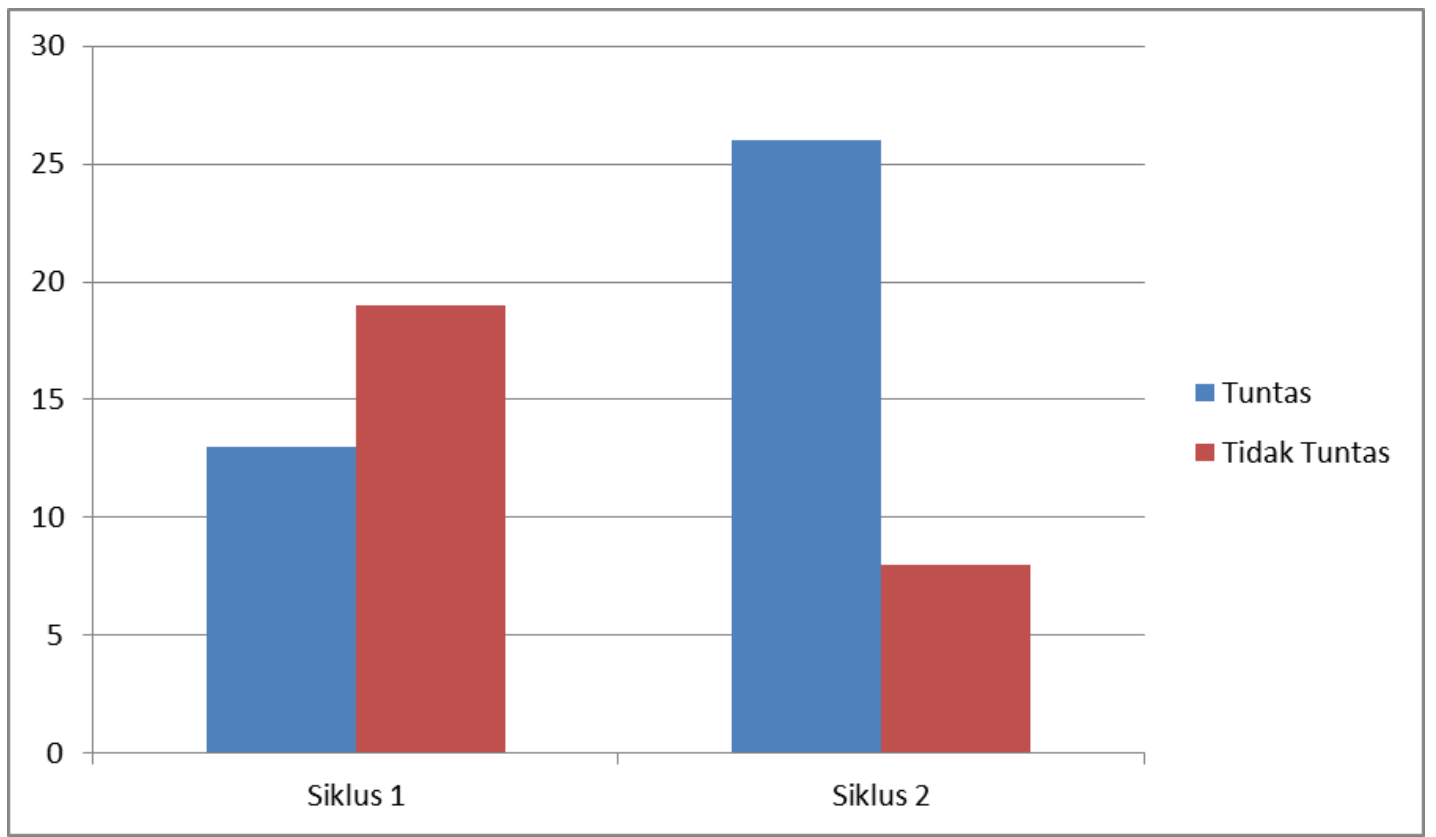

Gambar 4. Perbandingan Hasil Belajar Siswa pada Siklus I dan Siklus II 
Berdasarkan kegiatan pada Siklus I dan Siklus II yang telah dilakukan dapat dinyatakan bahwa penerapan model pembelajaran kooperatif tipe Jigsaw efektif digunakan pada materi bangun ruang sisi datar khususnya menghitung luas permukaan dan volume dari kubus, balok, prisma dan limas. Hal ini berdampak pada jumlah siswa yang memperoleh nilai di atas kriteria ketuntasan minimal juga mengalami peningkatan dari siklus I. dari hasil analisis tersebut dapat diketahui bahwa penerapan model pembelajaran kooperatif tipe jigsaw pada siklus II dinyatakan sudah berhasil telah mencapai indikator keberhasilan penelitian, melebihi $75 \%$ persentase ketuntasan dan dianggap sudah memuaskan.

\section{KESIMPULAN}

Hasil belajar siswa dapat ditingkatkan melalui model pembelajaran kooperatif tipe jigsaw dengan materi bangun ruang sisi datar dalam menentukan luas permukaan kubus, balok, prisma dan limas. Model pembelajaran yang tepat akan membuat siswa aktif, termotivasi, sehingga menciptakan suasana belajar kondusif dan menyenangkan dan akhirnya berpengaruh terhadap peningkatan hasil belajar siswa.

\section{DAFTAR PUSTAKA}

Arends. (1997). Model-model Pembelajaran Inovatif Berorientasi konstruktivitas. Jakarta : Prestasi Pustaka Publisher.

Arikunto, Suharsimi. (2007). Prosedur Penelitian Suatu Pendekatan . Jakarta : Rineka Cipta

Andrean Perdana :Materi inside. Blogspot. com . Pengertian belajar,ciri-ciri belajar dan hasil belajar.

Buku Paket Matematika Kelas VIII Semester Genap Kurikulum 2013 (Edisi Revisi)

Titis, Prabaningrun. (2016). Penerapan Model Pembelajaran Kooperatif Tipe Jigsaw Untuk Meningkatkan Motivasi Belajar Dan Hasil Belajar Sosiologi Siswa kelas XI IPS 2 SMA Negeri 1 Sidoharjo Wonogiri Tahun Pelajaran 2015/2016. Skripsi Universitas Sebelas Maret. Surakarta.

Fitriani. (2007). Pembelajaran Kooperatif Tipe Jigsaw dapat Meningkatkan Hasil Belajar Siswa Kelas VIII di SMPN. 4 Palu

Lie, Anita. (2004). Cooperative learning, Mempraktikkan Cooperative Learning di Ruang Kelas, Jakarta : Grasindo.

Nur, Mohamad. (2011). Model Pembelajaran Kooperatif. Surabaya : Pusat Sains \& Matematika Sekolah Unesa.

Sujadi Iman. 2016. Modul Guru Pembelajar teori Belajar Matematika. Jakarta.

Slavin, Raharja, 2012 Pengembangan Model Pembelajaran Kooperatif Jigsaw. Bandung http://pendidikan.blogspot.com/2010/04/teori Thorndike-dalam belajar.htlm. 